\title{
DNA Testing for Family Reunification in Canada: Points to Consider
}

\author{
Yann Joly ${ }^{1} \cdot$ Shahad Salman $^{1} \cdot$ Ida Ngueng Feze $^{1}$ • \\ Palmira Granados Moreno ${ }^{1}$ • Michèle Stanton-Jean ${ }^{2}$. \\ Jacqueline Lacey $^{3}$ - Micheline Labelle ${ }^{4}$. Janet Dench ${ }^{5}$. \\ Edward S. Dove ${ }^{6}$ - Idil Atak ${ }^{7}$. Coline Bellefleur ${ }^{8}$. \\ Torsten Heinemann $^{9,10}$ • Hugues Langlais ${ }^{11} \cdot$ Roger Love $^{12}$
}

Published online: 7 May 2016

(C) The Author(s) 2016. This article is published with open access at Springerlink.com

\begin{abstract}
Countries have adopted different laws, policies, and practices that allow immigration officers to request in certain cases DNA tests to confirm biological relationships in the context of family reunification. In Canada, Citizenship and Immigration Canada has adopted a policy of suggesting DNA testing only as a last
\end{abstract}

Palmira Granados Moreno

palmira.granadosmoreno@mcgill.ca

1 Centre of Genomics and Policy, Department of Human Genetics, McGill University, 740 Docteur Penfield, Room 5101, Montréal, Québec H3A 0G1, Canada

2 Centre de Recherche en Droit Public, Université de Montréal, Pavillon Maximilien-Caron, 3101 chemin de la Tour. Bureau A-8418, Montréal, Québec H3T 1J7, Canada

3 Cabinet Me. Jacqueline L. Lacey, Avocats 83 Saint-Paul West, Montréal, Québec H2Y 1Z1, Canada

4 Sociology Department, Université du Québec à Montréal, C.P. 8888, succ. Centre Ville, Montréal, Québec H3C 3P8, Canada

5 Canadian Council for Refugees, 6839 Drolet \#301, Montréal, Québec H2S 2T1, Canada

6 School of Law, University of Edinburgh, Old College, South Bridge, Edinburgh EH8 9YL, UK

7 Ryerson University and Chaire de Recherche en immigration, ethnicité et citoyenneté, 350 Victoria Street, Office JOR 828, Toronto, Ontario M5B 2K3, Canada

8 Canadian Muslim Lawyers Association, Cabinet TBPK s.e.n.c.r.1 Montréal Québec, 505 Boulevard René Lévesque, Bureau 1250, Montréal, Québec H2Z 1Y7, Canada

9 Institute for the Study of Societal Issues, University of California, Berkeley, 2420 Bowditch Street \# 5670, 94720-5670 Berkeley, California, USA

10 Institute of Sociology, Universität Hamburg, Allende-Platz 1, Hamburg 20146, Germany

11 Cabinet Me. Hugues Langlais, avocats Montréal Québec, 1470 Rue Peel, Montréal, Québec H3A 1T1, Canada

12 Policy and Research, African Canadian Legal Clinic, 250 Dundas Street West, Suite 402, Toronto, Ontario M5T 2Z5, Canada 
resort in cases where no documentary evidence has been submitted or where the evidence provided is deemed unsatisfactory. However, in practice, there have been concerns on the increasing use of DNA tests in family reunification processes of nationals from certain regions including Africa, Asia, and Latin America. Moreover, the Immigration and Refugee Protection Regulations (IRPR) presents a biological definition of family as a determinant of parenthood in the context of family reunification that is inconsistent with the psychosocial definition used in provincial family laws. Although there are cases that can justify the request for DNA tests, there are also significant social, legal, and ethical issues, including discrimination and unfair practices, raised by this increasing use of genetic information in immigration. This policy brief identifies points to consider for policymakers regarding the use of DNA testing in Canadian family reunification procedures. These include (1) the need to refine the policy of "using DNA testing as a last resort" and its implementation, (2) the need to modify the definition of "dependent child" under the IRPR to reflect the intrinsic reality of psychosocial family ties, and (3) the importance of conducting more research on the use of DNA testing in other immigration contexts.

Keywords DNA testing - Immigration · Family reunification · Biological child ·

Discrimination

\section{Introduction}

Developments in genetic testing technology enable more accurate prediction of individuals' future health and their unique identification (Baldassi 2007, p. 5; Joly et al. 2015; Weiss 2011). In Canada, as in many other jurisdictions (Heinemann and Lemke 2013, p. 811; Taitz et al. 2002, p. 21), immigration officers can ask for DNA tests to prove biological relationships in the context of family reunifications, which refers to the possibility for an individual to reunite in Canada with a family member. (Citizenship and Immigration Canada 2007) ${ }^{1}$

As in other countries, the use of DNA testing in the immigration context in Canada commenced in the 1990s, though official statistics on this practice remain mostly unavailable (Heinemann and Lemke 2013, p. 811; Taitz et al. 2002, p. 21; LEXBASE-The International Information Network for Canadian Immigration Practitioners, (2011) February Report, 22(2); “Immigrant DNA testing cited: DNA test used to settle cases" Vancouver Sun (14 march 1991) A11). ${ }^{2}$ Countries have set different laws, rules, and guidelines permitting immigration officers to use DNA testing

\footnotetext{
${ }^{1}$ Family reunification of Canadian citizens or permanent residents is known as "family sponsorship." Other forms of family reunification also exist in Canadian law. See Neighborhood Legal Services "Guide to Family Reunification in Canada," online: <http://www.familyreunification.ca/uploads/4/4/3/9/4439251/guide to family_reunification.pdf>, p. 9. In Canada, family reunification is set as an important objective of its immigration system. See IRPA 2015, sec. 3. For a general definition of family reunification, see Heinemann and Lemke 2014, p. 492.

${ }^{2}$ Citizenship and Immigration Canada (CIC) estimated that 3500 DNA samples were taken in 2009 to establish biological relationship. LEXBASE-The International Information Network for Canadian Immigration Practitioners, (2011) February Report, 22(2). In response to an access to information demand, CIC replied that there was no record found related to the number of requests and cases involving DNA testing for sponsorship.
} 
to establish the existence of a biological relationship. Citizenship and Immigration Canada (CIC) has opted for an approach where DNA testing is to be suggested as a last resort when no documentary evidence has been submitted or when the evidence (e.g., birth certificate, photocopy of citizenship certificate, marriage certificate) provided is deemed unsatisfactory (Citizenship and Immigration Canada 2013, p. 11; Citizenship and Immigration Canada 2006, p. 16). The increasing number of requests for DNA testing has come to the attention of the media and researchers. In Canada, the use of DNA testing in immigration should be closely scrutinized given the psychosocial impacts involved, the potential risk of genetic discrimination, and the growing number of judicial recourses observed (see Ngueng Feze and Joly; Heinemann et al. 2013, pp. 184-185). Facilitating family reunification is an important objective of the Canadian immigration system. ${ }^{3}$ The adoption of misaligned policies by CIC can hinder the fulfillment of this objective and negatively impact Canada's reputation as a welcoming country with immigration policies that reflect humanitarian values deeply rooted in Canadian society. (CIC Report on Plans and Priorities 2015).

Following a short overview of the context, this policy brief identifies essential policy points to consider regarding the use of DNA testing in Canadian family reunification procedures. Points discussed pertain particularly to (1) the need to refine the policy of "using DNA testing as a last resort" (CIC DNA Policy) and its implementation, (2) the need to modify the definition of "dependent child" under the Immigration and Refugee Protection Regulations (IRPR) to reflect the intrinsic reality of psychosocial family ties, and (3) the importance of promoting research on the use of DNA testing in other immigration contexts.

\section{Context}

The use of DNA testing in the context of immigration fits within ongoing general debates related to immigration and citizenship. These debates include the challenge of balancing the control of borders with the right to international mobility, as well as the recognition of non-Canadian normative frameworks and values, such as those related to the concept of family or marriage, within the limit imposed by international human rights standards. There is also a recurring debate in immigration concerning the legitimacy and extent of the selection of immigrants, highly qualified migrant workers, investors, and entrepreneurs. On the one hand, the context of globalization has encouraged mobility of individuals across borders; on the other, for economic and security concerns, countries have tightened their immigration selection criteria (Labelle 2015), for instance, by limiting family reunification and requesting DNA testing. Canada, like many other countries, has been frequently altering the parameters of the "ideal immigrant," providing changing sets of rules and requirements (Neborak 2013, p. 5).

In 2001, Canada made an important reform in its immigration law by introducing a new immigration bill, the Immigration and Refugees Protection Act (IRPA 2015) (Neborak 2013, p. 5). IRPA's new regulation introduced the concept of "biological child," thus restricting family reunification to biologically linked children and setting

\footnotetext{
${ }^{3}$ In Canada, family reunification is set as an important objective of its immigration system. See IRPA 2015, sec. 3.
} 
aside the psychosocial ties in establishing bona fide relationships. This requirement came to create a gap with existent provincial laws that recognize filiation based on nonbiological parenthood (Children's Law Reform Act 1990, sec. 1, 4, and 8; Quebec Civil Code, sec. 552-525), resulting in an unnecessary distinction among children that are Canadian citizens and those that are not. The biological link required in the concept of the "biological child" seems inconsistent with the Convention of the Rights of the Child (Convention of the Rights of the Child 1989, p. 3, s. 10(1)), ${ }^{4}$ in which it is possible to derive a broader understanding of the concept of "family." Canada must also consider its commitment under the Universal Declaration of Human Rights and the International Covenant on Economic, Social and Cultural Rights in which the right to family reunification is recognized under the right to the protection of the family. ${ }^{5}$

DNA-based identity testing for family can be defined as the

use of technology to establish or rule out a relationship of genetic relatedness between at least two biological samples [...] includ[ing] testing to determine the degree of genetic relatedness between two or more persons (e.g., paternity testing) and testing to determine the identity of a person or the remains of a person (Anderlik and Rothstein 2002, p. 215).

CIC DNA policy involves direct paternity or maternity testing using blood samples. To determine kinship, the test looks for shared alleles in the STR markers ${ }^{6}$ of the mother, father, and child. The CIC DNA policy requires results that, from a scientific standpoint, are at least $99.8 \%$ reliable (Citizenship and Immigration Canada 2006, p. 16; Citizenship and Immigration Canada 2013, p. 11). In the immigration context, the use of DNA testing is perceived as providing some advantages over other procedures and means of identification, as it is precise and can establish biological relatedness between parents and children, but also between other family members (Heinemann et al. 2013, pp. 184-185). Two pieces of legislation constitute the federal legal immigration framework in Canada, IRPA and IRPR. However, the recourse to DNA testing is not embedded in the legislation, but rather it is included in CIC's administrative policies. The Operational Procedure Manual (CIC OP 1) states that:

A DNA test to prove relationship is a last resort. When documentary submissions are not satisfactory evidence of a bona fide relationship, officers may advise

\footnotetext{
${ }^{4}$ Convention on the Rights of the Child 1989, p. 3, s 10(1); Canada became a signatory of the Convention on the Rights of the Child in 1990 and ratified it in 1991.

${ }^{5}$ The three instruments recognize that everyone has a right to form a family and a right to a family life. They also assert that State Parties shall uphold and protect these rights. This protection implies that processes of family reunification shall be dealt with in a humane and expeditious manner. For more details on these human rights responsibilities, see Heinemann and Lemke 2014, p. 492, Weiss 2011, p. 3; Feller et al. 2003; and Kenny 2011, p. 186.

${ }^{6}$ STR (short tandem repeat) is a short sequence of DNA that repeats in the same location of an individual's DNA. STR markers are used to determine kinship between two individuals because it is unlikely that two unrelated individuals have the same alleles or repetitions for a particular STR marker. Each child inherits one allele from the father and one allele from the mother for each STR marker. However, there may be mutations in the child's and the parents' genotypes that could create inconsistencies in certain sections of the test. With this in mind, a standard test will analyze the STR of 12-16 loci. (Butler 2005; Barata 2012; Dove 2013)
} 
applicants that positive results of DNA tests by a laboratory listed in Appendix E are an acceptable substitute for documents. (Citizenship and Immigration Canada 2013, p. 11).

This CIC DNA policy lacks clarity in its scope and application. Consequently, it has been inconsistently enforced. Although DNA testing can certainly be considered necessary in some cases (e.g., when applicants have no other convincing evidence, such as valid birth certificates, to prove a family relation or when even if they have it, its authenticity is questioned by the immigration authorities) (Heinemann et al. 2013, p. 202; Taitz et al. 2002, p. 29; Dove 2013, p. 514), it raises important social, legal, and ethical issues specific to the use of an individual's genetic information potentially resulting in discriminatory practices, in addition to the broader ongoing sociopolitical debates on Canadian immigration and citizenship rules.

The use of genetic information outside the health and medical research context can be conducive to genetic discrimination (Joly et al. 2015; Otlowski et al. 2012; Davey 2015). Genetic discrimination can be defined as a differential treatment based on an individual's or a group's genetic information or characteristics. In the immigration context, based on the existing literature, case law, and immigration policy documents, such discrimination can take different forms. Some authors have identified certain trends including, for instance, more frequent requests and use of DNA testing in cases involving applicants from certain countries, potentially leading to a discriminatory application of the DNA last resort policy (Baldassi 2007, p. 53; Taitz et al. 2002, p. 25). Moreover, a review of CIC's 13 public applicant information guides (Citizenship and Immigration Canada 2002) has demonstrated that the possibility of undergoing DNA testing is mentioned only in the information guides addressed to applicants from African countries (Citizenship and Immigration Canada 2014b), without the CIC DNA policy being clearly presented, which makes the information provided unclear and potentially misleading. Whereas the CIC DNA policy seems to suggest the use of DNA testing as a "last resort," it fails to clarify what constitutes "last resort" and to provide any guideline on the type of cases where it could be justified to suggest providing a DNA test. Furthermore, mentioning in the information guides for African countries that DNA testing may shorten the time to verify the family relationship may mislead African applicants into thinking that they will have a faster processing when in fact, according to the available evidence, they may experience considerable delays. (Canadian Council for Refugees 2011)

Canadian human rights instruments protect all individuals from discrimination on the basis of enumerated traits and characteristics that have historically been associated with exclusion, marginalization and disadvantage, and analogous (i.e., those connected by interpretation to the enumerated grounds) grounds (Canadian Human Rights Act 1985; Charter of Human Rights and Freedoms). ${ }^{7}$ Under section 15,

Every individual is equal before and under the law and has the right to the equal protection and equal benefit of the law without discrimination and, in particular,

\footnotetext{
${ }^{7}$ Only the Charter of Rights and Freedoms protects against discrimination on analogous grounds. Human rights statutes throughout Canada (including the Quebec Charter) protect only on the basis of enumerated grounds.
} 
without discrimination based on race, national or ethnic origin, colour, religion, sex, age or mental or physical disability.

However, current practices using DNA testing in immigration and the genetic or biological link required in the concept of "biological child" could be considered discriminatory if their application results in otherwise unjustifiable distinctions based on national or ethnic origin, race, ethnicity or family, or civil status. Indeed, as previously noted by Baldassi in her analysis of the application of the last resort policies, the current practice of testing most people from certain countries, regardless of the evidence they present in support of their application, is unlikely to pass scrutiny under the Sec. 15 of the Charter (Baldassi 2007, p. 19). Moreover, she also noted that despite the increasing diversity of family structure in Western countries, those nationals are not required to prove their biological link through DNA testing as other individuals from non-Western countries. Indeed, some Western applicants are not asked for DNA samples, despite questionable documentary evidence (ex. birth certificate of a child that has been adopted generally list the non-biological mother's name) or even explicit proof that the child is not genetically related to the sponsor (ex. assisted reproduction with donated genetic material). (Baldassi 2007, p. 19, 25). Therefore, one of the arguments that could eventually be presented before the courts could concern the discriminatory practice of not affording all applicants the equal opportunity to present proof of relatedness that is neither genetic nor confined to a legal document (Baldassi 2007, p. 19). Given the growing number of Canadian cases where the courts have held that DNA tests ought not to have been requested by CIC officers and the ongoing studies being conducted on this topic, (Ngueng Feze and Joly), there may be evidence supporting the potential violation of section 15 .

The introduction of DNA testing in the family reunification process raises procedural, ethical psychosocial, and technical issues leading to erroneous rejection of applications (see Karlsson et al. 2007; Heinemann et al. 2013, p. 185; Karlsson et al. 2007). For instance, rare cases of de novo mutations in the offspring's $\mathrm{DNA}^{8}$ may lead to the erroneous exclusion of maternity or paternity even though a biological relationship exists. (Heinemann et al. 2013, p. 185; Murdock 2008, p. 1523) Irrespective of potential human or technical errors, DNA test results can be devastating for the families involved, as they may cause additional important psychosocial challenges that may require counseling (e.g., a mother having to admit to family members that her child was the product of rape or of an extramarital affair) (Dove 2013). This is particularly important in the context where DNA testing can uncover non-biological paternity unsuspected by the father.

Federal courts and administrative tribunals have had to deal with a substantial number of cases reflecting the multiple challenges previously identified. An extensive analysis of the case law was conducted and revealed inconsistencies leading to an unnecessary level of unpredictability in the outcome of the application of CIC DNA policy to individual cases (Ngueng Feze and Joly). Indeed, Federal courts and administrative tribunals have reviewed some cases where the immigration officer required DNA testing, even though sufficient evidence had been provided or, without allowing

\footnotetext{
${ }^{8}$ This rare type of mutations may occur when DNA bases are deleted or multiplied during the process of division and replication of a fertilized egg. (Murdock 2008, p. 1523)
} 
the applicant the opportunity to present some other types of evidence. Cost is also an important aspect to consider in a request to undergo DNA testing. Even though the cost of the test has somewhat decreased with time, it may still remain prohibitive for less fortunate applicants. Furthermore, all the expenses associated with the test, such as traveling to sometimes distant places where the DNA samples are collected, need to be taken into account as well. ${ }^{9}$ In several cases, the cost of testing was found to be unduly burdensome, preventing applicants from reuniting with their family. (Heinemann et al. 2013, p. 201; Canadian Council for Refugees 2011)

Given the diverse issues surrounding the use of DNA testing and the lack of clarity in the application of CIC DNA policy raised particularly in case law, a multidisciplinary expert working group met to debate. The following text presents a series of policy points to consider addressing the issues raised by the current DNA testing practice in Canadian family reunification process.

\section{Methods}

The process leading to these points to consider began with the identification of issues through a review of the case law on use of DNA testing in Canadian immigration (Ngueng Feze and Joly) and a broad comparative review of national and international studies on the use of DNA testing for family reunification. This research informed an issue paper on the use of DNA testing in the family reunification process, which was circulated to the working group of experts representing a variety of interests and disciplines concerned with the use of DNA testing in family reunification. The working group met in Montreal on April 30th and May 1st, 2015 to agree on a set of points to consider. The first day of the workshop consisted of plenary presentations on DNA and immigration by selected experts from the group followed by a period of open discussions. On the following day, the working group developed the points to consider reaching a consensus on the content and formulation of each policy point.

\section{Points to Consider for Policy Options}

\section{Policy of "DNA Testing as a Last Resort"}

Decisions from the federal courts of Canada and administrative tribunals on the recourse to DNA testing in family reunification have not provided the consistency and reliability required to inform stakeholders of the state of the law. The current application of CIC DNA policy for the use of DNA testing in family reunification processes has caused economic, physical, and psychological distress to families that were often already in a vulnerable position due to hardships related to immigration or endured in their country of origin or abroad. Furthermore, given that among CIC's 13

\footnotetext{
${ }^{9}$ For example, according to the Canadian Council for Refugees Report, in September 2011, a 3-year-old Kenyan girl was required to go to the IOM office in Nairobi to have her blood sample taken as part of her ongoing immigration procedure. Given that the girl lived in a part of Kenya that was far away from Nairobi and her mom lived in Canada, the mother had to pay for the travel costs of her daughter and a caretaker in addition to paying for the test.
} 
information guides for applicants, only the one for Africa (Citizenship and Immigration Canada 2002) mentions the possibility of undergoing DNA testing, but without explicitly discussing CIC DNA policy, it is very difficult to ensure that CIC DNA policy is systematically implemented in a fair manner towards all applicants. Thus, there is a need to standardize the practice by providing detailed and consistent guidelines for the implementation of CIC DNA policy. Finally, the current practice does not sufficiently take into account the obligations of Canada as stipulated in section 3 and 10 of the Convention of the Rights of the Child ratified in 1991. It is also detrimental to Canada's reputation as a welcoming country with immigration policies that reflect humanitarian values deeply rooted in Canadian society. (CIC Report on Plans and Priorities 2015)

\section{Point to Consider 1.1: the Revised CIC DNA Testing Policy}

The framework for CIC DNA policy must be strictly defined so as to properly oversee a consistent implementation of the use of DNA testing as a last resort in a refined policy where:

1. CIC should provide specific guidelines delimiting the situations where evidence can be considered insufficient by its immigration officers.

2. Immigration officers should offer applicants reasonable opportunities to provide alternative documents or information before suggesting DNA testing. For instance, in addition to birth, marriage, and death certificates, other useful forms of evidence that could be accepted from applicants include photos, sworn declarations, proof of regular money transfers, and communication exchanges. (Heinemann and Lemke 2015, p. 16) These alternative forms of evidence could, without imposing stress on minors, confirm the existence of a family relationship. Interviews could also be a helpful form of evidence to prove a family relationship, irrespective of the existence of a biological link. However, it should be recognized that this last alternative might sometime impose stress on young children and violate applicants' privacy, given the extremely personal nature of many of the questions that could be asked. Therefore, it would be important to explain to applicants the risks associated with these alternatives so they can make an informed decision. ${ }^{10}$

3. The letter of invitation to undergo DNA testing sent by CIC to the applicant should systematically include specific and detailed reason(s) selected from a checklist of acceptable forms of evidence based on the new aforementioned guidelines to justify the officer's assessment that the evidence provided was not satisfactory and that, given the lack of other alternative options, DNA testing is necessary.

This refined CIC DNA policy must be applied consistently by immigration officers regardless of the country of origin or of residence of the applicant. The margin of discretion afforded to immigration officers in this matter should be minimal.

\footnotetext{
${ }^{10}$ For a more detailed analysis on the ethical aspects regarding the use of interviews in family reunification processes, see (Weiss 2015, pp. 79-92)
} 


\section{Point to Consider 1.2: Financial Assistance}

Under the refined CIC DNA policy, the substantial costs associated with DNA testing should not prevent family reunification for less financially fortunate individuals. DNA testing should be done using saliva (mouth swab), which is not only less intrusive, but could also reduce current costs and delays associated with the current practice of using blood-based testing. ${ }^{11}$ If families can demonstrate their incapacity to pay for testing without incurring financial hardship, CIC should be responsible for providing financial assistance in the form of a loan.

Point to Consider 1.3: Communication Tools for Sponsors, Applicants, and the Public at Large

CIC should combine information on DNA testing into one single guidance document (ex. a specific operational manual or guide on DNA testing). This guidance document should be made publicly available and used to create a short pamphlet, drafted in lay terms that would accompany invitation letters to undergo DNA testing. The information provided should reflect the actual practice, avoid misleading or coercive terminology, and enable applicants to make an informed decision. The documents should also provide a simple explanation of DNA testing for immigration purposes. A notice concerning the potential psychosocial risks related to the discovery of a lack of biological filiation and details about the possible need for counseling to understand the test results and help cope with the psychosocial impact should be provided in the pamphlet. General information on cost and delay related to testing must also be included. In addition, CIC should maintain and provide applicants with a list of some of the laboratories that are accredited by the Standards Council of Canada and authorized to conduct DNA testing for immigration purposes that have up to date consent, confidentiality, and privacy policies in place. CIC should also state in the pamphlet that it will use reasonable efforts to ensure the confidentiality of testing and results and that it will not share this information with third parties, unless otherwise provided by law or court order. Finally, the pamphlet should clearly explain that undergoing the test is entirely voluntary and that the laboratory should have a procedure to enable informed consent.

\section{Point to Consider 1.4: Internal Training and Communication}

CIC should disseminate the refined CIC DNA policy to immigration officers and stakeholders in order to promote a coherent and predictable interpretation of the refined CIC DNA policy in family reunification cases. In addition, considering the important number of cases where the decision to suggest DNA testing was deemed not warranted (Ngueng Feze and Joly), appropriate training will be key to ensure that the revised policy is applied consistently in the same manner. This ongoing training process would be a good opportunity to raise awareness among immigration officers about the various issues surrounding the use of DNA testing in family reunification cases, as well as an

\footnotetext{
${ }^{11}$ Currently, DNA profiles are extracted from blood samples. See Citizenship and Immigration Canada 2006, p. 16. This reports suggests that a blood test is almost twice as expensive. Cancer Research Network, p. 20.
} 
avenue for the officers to voice their concerns, share their experiences, and exchange best practices. Therefore, this training should be held recurrently, be periodically revised, and used as a means to further existing collaborations and exchanges among $\mathrm{CIC}$ officers to further optimize relevant associated procedures, processes, and policies.

\section{Point to Consider 1.5: Increased Transparency}

Given the unique and sensitive nature of DNA evidence, there is a need for increased transparency of the process of using DNA tests for family reunification. CIC should collect anonymous statistics on the number of cases where DNA testing is suggested by immigration officers in the context of family reunification, the number of cases where the tests are actually undertaken by sponsors and applicants, and the outcome of the DNA test. This data should also include the country of origin of the families involved, the cost, and the delays associated with the procedure. These statistics should be made available to the general public on CIC's website and regularly updated, for example, on a semi-annual basis.

\section{Point to Consider 1.6: Ensure High Ethical Standards and Informational Privacy}

In cases where DNA tests are suggested, CIC should ensure that recommended laboratories accredited by the Standards Council of Canada have established a structured ethical process that includes:

1. A policy addressing ethical issues associated with the return of the test results to the tested applicants, the sponsor, and CIC. This should integrate specific policies for the return of results concerning minor children;

2. Information that would enable applicants to make an informed decision. This information, which could be provided in the pamphlet we recommended in our "Point to Consider 1.3: Communication Tools for Sponsors, Applicants, and the Public at Large" section, includes an overview of the test, probable outcomes, psychosocial risks, costs, potential delays, etc. It should also give information about the counseling available to the applicants, in case they need professional psychological help to better handle the test results and the psychosocial impact they may have. The laboratory should go through this information with the applicants and seek their consent if and when they decide to undergo the test;

3. A policy concerning the timely destruction of the genetic sample and associated data after test results have been sent to CIC and the sponsor, or the applicants and all parties have had a reasonable time to contest the validity of the results.

\section{Requirement of a Biological Link Between Child and Parents in the Immigration and Refugee Protection Regulations}

The definition of "dependent child" in the IRPR presents a biological definition of family that is inconsistent with Canadian provincial family laws, which favor a more psychosocial definition. Moreover, the Citizenship Act does also recognize nonbiological children for citizenship purposes, including where human reproduction and 
surrogacy are involved, which creates additional inconsistency within immigration laws (Citizenship Act 1985, sec. 2(1); Citizenship and Immigration Canada Government of Canada 2014a). This unnecessary biological distinction between dependent children has the effect of applying a different, less favorable legal regime to certain Canadian citizens and permanent residents, as well as refugees and asylum seekers, in the context of family reunification in Canada. Furthermore, this regime is inconsistent with Canada's obligation as enounced in sections 3 and 10 of the Convention of the Rights of the Child. The Convention recognizes the existence of rights and duties of extended family members towards a child (Convention on the Rights of the Child 1989, sec. 5). The requirement of a biological link between child and parents has also been conducive to a derogatory and contradictory application of CIC DNA policy, which prevents the recourse to more traditional documentary evidence of social filiation and creates interpretative challenges for the administrative tribunals and federal courts of Canada.

\section{Point to Consider 2.1: Redefining the Term "Dependent Child"}

In section 2 of the IRPR in the definition of "dependent child" (a) (i), the Canadian legislator should remove the word "biological" to make this definition more inclusive of the different notions of "family" as defined in provincial laws, public policies, and international human rights fundamental texts and to integrate the often complex psychosocial realities intrinsic to contemporary family relationships.

\section{The Use of DNA Tests by Immigration Officers in Other Immigration Contexts}

Although this topic was not the central objective of our assessment, we note with concern that the use of DNA testing is also prevalent in other immigration contexts, outside of family reunification processes. For instance, DNA testing could be used to prevent deportation of a father when he can prove he has a minor child who is a Canadian citizen or permanent resident. It could also be used to expose an arranged marriage between siblings or to confirm a marriage between two individuals when they cannot provide a marriage certificate, but they can prove they have biological children together.

\section{Point to Consider 3.1: Establishing a Comprehensive Framework for DNA Testing in All Immigration Procedures}

The sensitive and familial nature of human DNA requires that its use in immigration procedures be carefully delineated to cases where it is absolutely necessary to prevent fraud. Such use of genetic testing should always be explained and documented in a transparent manner by CIC on its manuals, policies, and website.

\section{Point to Consider 3.2: Conducting Further Research to Better Inform Future Laws and Policies}

To increase our knowledge of the use of DNA testing by immigration officers in this and other immigration contexts, independent studies by academic researchers and non- 
profit organizations should be encouraged by funding organizations and relevant government agencies.

\section{Concluding Remarks}

The current CIC DNA policy allowing immigration officers, as a last resort, to ask for DNA tests to prove biological relationships in the context of family reunification raises significant ethical, legal, and social issues. These issues include the possible adverse psychosocial impact of genetic test results, the potential for genetic discrimination, and the growing number of judicial recourses observed. The narrow definition of "dependent child" in the IRPR is also ill advised at a time where a growing number of parents resort to assisted procreation to have children. Considering the important issues and values at stake, these problems need to be addressed as a matter of urgency.

This policy brief puts forward essential policy points to consider regarding the use of DNA testing in family reunification in Canada. The adoption of the proposed refined CIC DNA policy and the modification of section 2 of the IRPR to omit the word "biological" should benefit all stakeholders involved, as these changes address key policy points of concern in a matter consistent with Canadian national and international human rights commitments. CIC will need to remain vigilant to ensure that the refined policy is applied fairly and consistently to preserve Canada's longstanding reputation as a nation that welcomes immigrants and refugees. In addition, further research on the different legal, ethical, and social issues raised by genetic testing in the larger immigration context are needed to better inform future policies and our understanding of the various implications and challenges faced by agencies and governments in the implementation of these policies.

Acknowledgments The authors would like to thank the observers Dominique Elien-Massenat and Yvette Mputu from Citizenship and Immigration Canada and Fiona Keith and Marcella Daye from the Canadian Human Rights Commission. The authors are also thankful to Professor Trudo Lemmens, Faculty of Law, University of Toronto, for critically reading the manuscript and for his helpful comments.

\section{Compliance with Ethical Standards}

Funding Fonds de Recherche Societe et Culture. Yann Joly. 2015-AN-186368

Fondation du Barreau du Quebec. 2013-2014 Grant Yann Joly. L'encadrement juridique des tests d'ADN dans le context du processus de parrainage des membres de la famille des immigrants Canadiens

Open Access This article is distributed under the terms of the Creative Commons Attribution 4.0 International License (http://creativecommons.org/licenses/by/4.0/), which permits unrestricted use, distribution, and reproduction in any medium, provided you give appropriate credit to the original author(s) and the source, provide a link to the Creative Commons license, and indicate if changes were made.

\section{References}

(1991). Immigrant DNA testing cited: DNA test used to settle cases. Vancouver Sun A11.

Anderlik, M. R., \& Rothstein, M. A. (2002). DNA-based identity testing and the future of the family: a research agenda. American Journal of Law \& Medicine, 28(2-3), 215-232. 
Baldassi, C. L. (2007). DNA, discrimination and the definition of family class: M.A.O. v. Canada (Minister of Citizenship and Immigration). Journal of Law and Social Policy, 21, 5.

Barata, L. (2012) Genetic testing in immigration for family reunification: ethical, legal and social implications. Doctor of Philosophy Dissertation. University of Washington https://digital.lib.washington.edu/ researchworks/handle/1773/22022. Accessed March 7, 2016.

Butler, J. M. (2005). Forensic DNA typing: biology, technology, and genetics of STR markers. USA: Elsevier Academic Press.

Canadian Council for Refugees (2011) DNA tests: a barrier to speedy family reunification. http://ccrweb.ca/ files/dnatests.pdf. Accessed March 11, 2016.

Canadian Human Rights Act., RSC 1985, c H-6.

Cancer Research Network. Specimen collection within the CRN: a critical appraisal. http://crn.cancer.gov/ publications/crn_specimen_collection.pdf. Accessed 3 July 2015

Charter of Human Rights and Freedoms. CQLR, c. C-12.

Children's Law Reform Act., RSO 1990, c C.12. Accessed 6 July 2015

Citizenship Act., RSC 1985, c C-29. https://www.canlii.org/en/ca/laws/stat/rsc-1985-c-c-29/latest/rsc-1985-cc-29.html. Accessed 12 June 2015

Citizenship and Immigration Canada (2002). Application to sponsor a member of the family class. http://www. cic.gc.ca/english/information/applications/fc.asp. Accessed 12 June 2015.

Citizenship and Immigration Canada (2006). OP 2 processing members of the family class. http://www.cic.gc. ca/english/resources/manuals/op/op02-eng.pdf.

Citizenship and Immigration Canada (2007). Family sponsorship. http://www.cic.gc.ca/english/immigrate/ sponsor/. Accessed 12 June 2015.

Citizenship and Immigration Canada (2013). OP 1 procedures. http:/www.cic.gc.ca/english/resources/ manuals/op/op01-eng.pdf. Accessed 12 June 2015.

Citizenship and Immigration Canada (2014a). Who is a parent for citizenship purposes where assisted human reproduction (AHR), including surrogacy arrangements, are involved. http://www.cic.gc.ca/english/ resources/tools/cit/admin/id/parent-assist.asp. Accessed 3 July 2015.

Citizenship and Immigration Canada (2014b). Sponsorship of a spouse, common-law partner, conjugal partner or dependent child living outside Canada. http:/www.cic.gc.ca/english/pdf/kits/guides/3912e.pdf. Accessed 12 June 2015.

Citizenship and Immigration Canada (2015) Minister's message in the CIC's report on plans and priorities 2015-2016 online: http:/www.cic.gc.ca/english/resources/publications/rpp/2015-2016/. Accessed 8 Mar 2016.

Convention on the Rights of the Child, New York, 20 November 1989 United Nations, treaty series, vol. 1577, p. 3; depositary notifications C.N.147.1993.TREATIES-5 of 15 May 1993 [amendments to article 43 (2)]; and C.N.322.1995.TREATIES-7 of 7 November 1995 [amendment to article 43 (2)].

Davey, J. (2015). Genetic discrimination in insurance. In G. Quinn, A. De Paor, \& P. D. Blanck (Eds.), Genetic discrimination: transatlantic perspectives on the case for a European level legal response. Abingdon: Routledge.

Dove, E. S. (2013). Back to blood: the sociopolitics and law of compulsory DNA testing of refugees. University of Massachusetts Law Review, 8, 466.

Feller, E., Türk, V., Nicholson, F., \& Refugees, O. of the U. N. H. C. for. (2003). Refugee Protection in International Law: UNHCR's Global Consultations on International Protection. Cambridge University Press.

Heinemann, T., \& Lemke, T. (2013). Suspect families: DNA kinship testing in German immigration policy. Sociology, 47(4), 810-826. doi:10.1177/0038038512454352.

Heinemann, T., \& Lemke, T. (2014). Biological citizenship reconsidered the use of DNA analysis by immigration authorities in Germany. Science, Technology \& Human Values, 39(4), 488-510. doi:10. $1177 / 0162243913509414$.

Heinemann, T., \& Lemke, T. (2015). Germany: the geneticisation of the family. In T. Heinemann, I. Helen, T. Lemke, U. Naue, \& M. G. Weiss (Eds.), Suspect families. DNA analysis, family reunification, and immigration policies. United Kingdom: Ashgate Publishing Limited.

Heinemann, T., Naue, U., \& Tapaninen, A.-M. (2013). Verifying the family? A comparison of DNA analysis for family reunification in three European countries (Austria, Finland and Germany). European Journal of Migration and Law, 15(2), 183-202. doi:10.1163/15718166-12342030.

Immigration and Refugee Protection Act., S.C. 2001, c.27 (2015). https:/www.canlii.org/en/ca/laws/stat/sc2001-c-27/latest/sc-2001-c-27.html. Accessed 12 June 2015

Immigration and Refugees Protection Regulations., SOR/2002-227. 
Joly, Y., Kim, R. J., Salman, S., \& Ngueng Feze, I. (2015). The use of genetic information outside of the therapeutic or health research relationship: an international perspective. In G. Quinn, A. De Paor, \& P. D. Blanck (Eds.), Genetic discrimination: transatlantic perspectives on the case for a European level legal response. Abingdon: Routledge.

Karlsson, A. O., Holmlund, G., Egeland, T., \& Mostad, P. (2007). DNA-testing for immigration cases: the risk of erroneous conclusions. Forensic Science International, 172(2-3), 144-149. doi:10.1016/j.forsciint. 2006.12.015.

Kenny, C. (2011). Positive, humane and expeditious? An analysis of ireland's implementation of its obligations in relation to family reunification under the CRC. Northern Ireland Legal Quarterly, 62(2).

Labelle, M. (2015). Le paradigme de la mobilité propose-t-il une perspective adéquate de l'immigration internationale ?, 17(1). http://ethiquepublique.revues.org/1590

LEXBASE - The International Information Network for Canadian Immigration Practitioners, (2011) February Report, 22(2).

Murdock, T. R. (2008). Whose child is this?: genetic analysis and family reunification immigration in France. Vanderbilt Journal of Transnational Law, 41, 1503.

Neborak, J. (2013). Family reunification? A critical analysis of citizenship and immigration Canada's 2013 reforms to the family class (No. RCIS Working Paper No. 2013/8). Ryerson Centre for Immigration \& Settlement. http://www.ryerson.ca/content/dam/rcis/documents/RCIS_WP_Neborak_No_2013_8.pdf. Accessed 12 June 2015

Neighbourhood Legal Services. Guide to family reunification in Canada. http://www.familyreunification.ca/ uploads/4/4/3/9/4439251/guide to family reunification.pdf.

Ngueng Feze, I., \& Joly, Y. The use of DNA testing in the context of family reunification in Canadian immigration. (unpublished).

Otlowski, M., Taylor, S., \& Bombard, Y. (2012). Genetic discrimination: international perspectives. Annual Review of Genomics and Human Genetics, 13, 433-454. doi:10.1146/annurev-genom-090711-163800.

Quebec Civil Code., R.L.R.Q. c C-1991.

Taitz, J., Weekers, J. E. M., \& Mosca, D. T. (2002). The last resort: exploring the use of DNA testing for family reunification. Health and Human Rights, 6(1), 20-32. doi:10.2307/4065312.

Weiss, M. G. (2011). Strange DNA: the rise of DNA analysis for family reunification and its ethical implications. Life Sciences Society and Policy, 7(1), 1. doi:10.1186/1746-5354-7-1-1.

Weiss, M. G. (2015). Ethical aspects of DNA testing for family reunification. In T. Heinemann, I. Helen, T. Lemke, U. Naue, \& M. G. Weiss (Eds.), Suspect families. DNA analysis, family reunification, and immigration policies. United Kingdom: Ashgate Publishing Limited. 